\title{
Bacillus spp.: Attractive Sources of Anti-cancer and Anti-proliferative Biomolecules
}

\author{
Umme Tamanna Ferdous ${ }^{\mathrm{a}}$, Md. Asaduzzaman Shishir ${ }^{\mathrm{b}}$, Shakila Nargis Khan ${ }^{\mathrm{a}}$, Md. Mozammel Hoqa ${ }^{*}$
}

\begin{abstract}
Cancer treatment remains as an expensive process due to the cost of sophisticated infrastructure development as well as its maintenance with skilled personnel. At the same time, the success rate is not very inspiring since non-specific target oriented medication could cause other health complexities leading to death. Research for alternative therapies aimed at minimizing the side effects of treatments and increasing the survival rates of patients includes routine explorations for anticancer agents from numerous sources (e.g. microbes, plants and nanoparticles). Anticancer activities of several bacterial components especially from Bacillus spp. were reported in many scientific reports. For economic production of these agents, potential strains from this genus could be feasible and sustainable for their long and successful utilization in industries. The review is therefore, focused on describing the available anticancer and anti-proliferative agents reported worldwide from Bacillus spp.
\end{abstract}

Keywords: Bacillus spp., anti-cancer, anti-proliferative, bioactive, cancer therapy.

Abbreviations: EMT, Epithelial-messenchymal transition; MTT3-(4,5-dimethylthiazol-2-yl)-2,5-diphenyltetrazolium bromide; XTT2, 3 -bis-(2-methoxy-4-nitro-5-sulfophenyl)-2H-tetrazolium-5-carboxanilide; B.P. CM- Conditioned medium of Bacillus polyfermenticus; ErbB2 and ErbB3 - Receptor Tyrosine protein kinase; E2F-1transcriptional regulator; cyclin D1- cell cycle regulator; PS- Parasporin;

\section{Significance|Potentials of Bacillus spp. in anti-cancer drug development.}

${ }^{*}$ Correspondence: Md. Mozammel Hoq, Professor, Department of Microbiology, University of Dhaka, Dhaka-1000, Bangladesh. Tel: 9661920-73/7734, +8801717083673,

E-mail: mhoq@du.ac.bd

Edited by Debananda S. Ningthoujam, PhD, Professor, Manipur University, India., and accepted by the Editorial Board August 8, 2018 (received for review May 4, 2018)

ICR- a strain of albino mice sent from the Institute of Cancer Research in the USA; $\mathrm{IC}_{50}-$ the maximal concentration of drug to cause $50 \%$ inhibition of biological activity of cancer cells; $\mathrm{ED}_{50}$ - the Dose (or Concentration) causing $50 \%$ of maximum effect for any measured biological effect of interest; $\mathrm{GI}_{50}{ }^{-}$ the concentration for $50 \%$ of maximal inhibition of cell proliferation; DHPS- 3,5-Dihydroxy-4-isopropylstilbene; HMA- 14-hydroxy-15-methylhexadecanoic acid; $\varepsilon$-PL- $\varepsilon$-Poly-L-lysine; Cry- Crystal; Cyt- Cytolytic; EPS- Exopolysaccharide; FTIR- Fourier-transform infrared spectroscopy; GC-MS- Gas Chromatography Mass Spectrometry; TLC- Thin layer chromatography.

\section{Background}

Cancer, the second leading cause of deaths worldwide, was responsible for 8.8 million mortalities in 2015 around the globe and approximately $70 \%$ of the cases occurred in low- and middle-income countries (WHO media center, 2017). Cancer is characterized by uncontrolled and invasive growth of cells which might spread to other parts of the body if not treated or cured at initial stage. The intrinsic factors influencing cancer development are age, hormonal factors, familial history and genetic predisposition (Devi, 1989; Henderson, Ross, \& Bernstein, 1988) whereas the extrinsic factors could be food habit, life style, smoking, alcohol abuse, exposure to toxic chemicals and ionizing radiation, certain infections by virus and bacteria etc. In addition, reactive oxygen species (ROS) and free radicals are considered as few of the most prolific inducers of cancer (Chew, Lim, Omar, \& Khoo, 2008; Clayson, Mehta, \& Iverson, 1994; Nandakumar, Jayaprakash, Rengarajan, Ramesh, \& Balasubramanian, 2011; Parsonnet, 1995).

Cancer is developed through multiple stages including initiation, promotion, malignant conversion and progression (Weston \& Harris, 2003). Spontaneous or carcinogen induced mutation in oncogenes oncogenes or tumor suppressor genes or cell cycle regula-

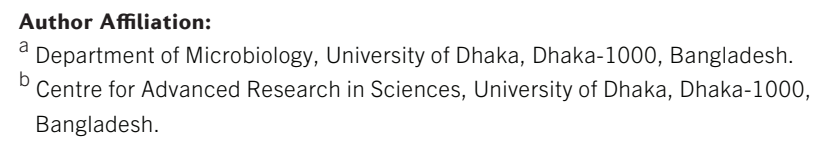

Ferdous UT, Shishir MA, Khan SN, Hoq MM (2018). Bacillus spp.: Attractive Sources of Anti-cancer and Anti-proliferative Biomolecules. Microbial Bioactives, 1(1), 033-045 
tor genes or genomic stability associated genes initiates carcinogenesis (Devi, 1989). Cells involved in the initiation stage are subject to subsequent changes in the promotion stage upon prolonged exposures to promoting stimuli (Devi, 1989). Malignant conversion, the third stage, is the transformation of a preneoplastic cell into the neoplastic one i.e. cell that expresses the malignant phenotypes. This could be caused by further genetic changes through exposure of preneoplastic cells to DNA-damaging agents or the activation of proto-oncogenes and inactivation of tumor suppressor genes (Weston \& Harris, 2003). In this stage, mutations in the genes of Ras proteins, the biological switches, and p53, the guardian of the genome, could lead to unregulated cell growth (Isoldi, Visconti, Maria, \& Castrucci, 2005). Finally, the tumor progression occurs by the expression of the more aggressive malignant phenotypes being accelerated by selection pressures or repeated exposures to carcinogenic stimuli with time. The malignant phenotypes have the tendency for genomic instability and uncontrolled growth (Devi, 1989; Weston \& Harris, 2003). Late in tumor progression, the fully malignant cells due to the accumulation of different genetic alterations (Yokota, 2000) lose their adherence capacity, detach from the tumor mass and invade the neighboring tissues leading to metastasis. Metastasis, a multi-stage process, mediates the spread and growth of metastatic tumor at a new metastatic site from the primary tumor involving invasive cancer cells (Sahai, 2007).

In several cases of human cancers, hypoxia-induced epithelial-mesenchymal transition (EMT) has been reported to be associated (Yeo et al., 2017). In hypoxic tumor microenvironment, prolonged hypoxic exposure (oxygen deficiency) of tumor cells might cause a tumor to acquire more aggressive phenotypes (Yeo et al., 2017). Cancer stem cells (CSCs), generated in part as a consequence of epithelial-mesenchymal transition (EMT) are increased in case of hypoxia-induced EMT during tumor progression. Although, EMT causes the conversion of the epithelial cells into mesenchymal cells through loss of cell polarity, the recent observation implies the critical role of EMT in tumor progression and modulation of an early stage tumor into an invasive malignancy (Yeo et al., 2017). This hypoxic microenvironment can also be generated by mitochondrial dysfunction where the mitochondrial metabolites accumulate in the cytoplasm due to the imbalance between glycolysis and oxidative phosphorylation (Roberts \& Jean, 2013).

Apoptosis or programmed cell death, a cellular defense mechanism, plays an important role in surveillance of tumors or other malfunctioning cells and it is also highly regulated and non-inflammatory (Steller, 1995). Apoptosis significantly differs from necrosis which is another form of cell death causing inflammation and group of cells death (Payne \& Miles, 2008). Apoptotic cells undergo several morphological and biochemical changes, such as chromatin condensation, nuclear segmentation, internucleosomal DNA fragmentation, cytoplasmic vacuolization, cell shrinkage and membrane blebbing with shedding of apoptotic bodies etc. (Häcker, 2000; Wyllie, 1992). Any defect in apoptosis process rendering uncontrolled proliferation of cells could also lead to cancer (Amran, 2017). Beyond self-defense mechanisms, carcinogenesis is prevented by several other modes e.g. the antioxidant effects. Antioxidants such as superoxide dismutase, catalase, glutathione peroxidase, reductase and S- transferases scavenge the ROS before their access into the cell for the target molecules (Halliwell, Gutteridge, \& Cross, 1992). Antioxidants like vitamins, $\alpha$ - and $\beta$-carotene, curcumin, lycopene, $\beta$-Cryptoxanthin, Esculetin, catechin etc., widely distributed in fruits and vegetables, play key roles in cancer inhibition by inducing oxidative stress in cancer cells. Likewise, fatty acids, amino acids and related compounds, flavonoids, resveratrol, different alkaloids and phenolic compounds from natural sources impede carcinogenesis (Reddy, Odhav, \& Bhoola, 2003).

The available cancer treatments such as surgery, radiation therapy, chemotherapy, immunotherapy, hormone therapy or combination of these therapies are long and expensive processes which require sophisticated infrastructure development and maintenance with skilled personnel. The success of a cancer therapy depends on its preferential wipeout of cancer cells with negligible toxicity to the normal cells (Amran, 2017). Targeted therapy using monoclonal antibodies is, therefore, turning to be useful gradually (Adams \& Weiner, 2005). Chemotherapeutic drugs interfere in cancer cell proliferation by cell cycle-specific or cell cycle-nonspecific manner and most common constituents of this are alkylating agents, heavy metals, anti-metabolites, cytotoxic antibiotics, topoisomerase inhibitors to prevent DNA replication or protein synthesis and damage mostly S- phase of cell cycle (Payne \& Miles, 2008). Although conventional treatments consisting of surgical resection, radiotherapy and chemotherapy are effective in managing many of the patients (generally prolonged life or permanent cure of cancer), almost $50 \%$ of the cases are unmanageable. Also the side effects such as pain, blood clots, fatigue, anemia, thrombocytopenia, constipation, diarrhea, or neurological complications and unpleasant to fatal infections are very often accompanied by these treatments (Aslam et al., 2014).

Research for alternative therapies, aimed at minimizing the side effects and increasing the survival rates, is a continuous process worldwide and in this connection, exploration for anti-cancer agents from numerous sources (e.g. microbes, plants and nanoparticles) are carried out routinely. Anticancer activities of several bacterial components were reported and a safe vaccine was developed by American physician William Coley a hundred years ago from killed bacterial species to treat sarcomas, carcinomas, lymphomas, and melanomas successfully (Hoption Cann, van Netten, \& van Netten, 2003; Zacharski \& Sukhatme, 2005). After several decades, a variety of natural and genetically modified non-pathogenic bacterial species were explored for their potency against tumor cells either for direct tumoricidal effects or tumoricidal molecules (Patyar et al., 2010). 
Microorganisms produce over 50000 metabolites among which more than $40 \%$ were reported with biological activities. Microorganism derived anticancer agents are Actinomycin, Bleomycin, Daunomycin, Doxorubicin, Epirubicin, Idarubicin, Mitomycin C, Geldanamycin, Rapamicin and Wortamannin which are used clinically to treat different forms of cancer mainly by blocking signal transduction pathways (Bhanot, Sharma, \& Noolvi, 2011). Bacteria produce over 3800 bioactive metabolites and of them, Bacillus spp. and Pseudomonas spp. are the most prominent sources, producing about 860 and 795 metabolites respectively (Bérdy, 2005). Polyketides, macrolactones, fatty acids, lipoamides, isocoumarin, lipopeptides and polypeptides are most abundant bioactive compounds from terrestrial and marine Bacillus spp. (Hamdache, Lamarti, \& Collado, 2011; Meena, Sharma, \& Kanwar, 2017) which exhibit a wide range of biological activities, such as antibacterial, antifungal, anti-algal, antioxidant, antifouling and most importantly anticancer activity (Baruzzi, Quintieri, Morea, \& Caputo, 2011; Hamdache et al., 2011). On the other hand, Bacillus spp. are the best characterized Gram-positive bacteria, being utilized industrially for long in producing microbial enzymes and therapeutically important chemicals, due to their feasibility in economic bioprocess (Liu et al., 2013; Papagianni, 2012). Hence, Bacillus species could be the appropriate sources of numerous bioactive molecules in developing new drugs for cancer therapy. This review, therefore, focuses on different Bacillus species synthesizing metabolites with anticancer activity and reports certain previous clinical trials in assessing their efficacy to cure cancer.

\section{Genus Bacillus}

A key distinguishing feature of the family Bacillaceae is the production of endospores which are round, oval, or cylindrical highly refractile structures formed within bacterial cells. This characteristics attracted the early interest of microbiologists which has continued still (Slepecky \& Hemphill, 2006). Certain other special features of the genus Bacillus are their aerobic nature (strict or facultative), rod shape and catalase production. Bacillus spp. are also renowned for producing antibiotics as secondary metabolites and ca. 169 of them were recorded so far. As for instance, different strains of B. subtilis and B. brevis produced 68 and 23 antibiotics respectively (Debabov, 1982). Usually, Bacillus species were reported to produce at least one extracellular enzyme besides different carbohydrates such as different proteases, penicillinases, nucleases, phosphatases, lipase, phospholipase $\mathrm{C}$, thiaminase, and bacteriolytic enzymes etc (Debabov, 1982). Beside production of large quantities of enzymes for industrial purposes, various biologically active molecules were identified, isolated and checked for their activities from Bacillus spp. and these are summarized in the Table 1 and Table 3.

\section{Bacillus amyloliquefaciens}

Bacillus amyloliquefaciens is an endophytic bacteria and this type of bacterium is one of the major sources of natural anticancer agents including anthracyclines, glycopeptides, aureolic acids, anthraquinones, enediynes, antimetabolites, carzinophilin and mitomycins (Blunt, Copp, Hu, Munro, \& Northcote, 2008).

\section{Bacillus amyloliquefaciens MD-bl}

Bacillus amyloliquefaciens MD-bl, isolated from the medicinal plant Ophiopogon japonicas was reported for its exopolysaccharides exhibiting dose-dependent inhibitory effects against the gastric carcinoma cell lines, MC-4 and SGC-7901 cells, with an $\mathrm{IC}_{50}$ of 19.7 and $26.8 \mu \mathrm{g} / \mu \mathrm{l}$, respectively, as revealed in MTT assay (C. Li, 2013). Polysaccharides are a group of water-soluble bioactive compounds associated with immune system modulation, including antitumoral, antiviral and antioxidant activities (Strobel et al., 2004). Upon administration, cancer cells were found to be damaged or dead with evident morphological abnormalities and mitochondrial dysfunction, indicating the apoptosis inducing effect by the polysaccharides. This was the first discovery of such anticancer exopolysaccharides derived from the genus Bacillus (C. Li, 2013).

\section{Bacillus amyloliquefaciens AK-O}

Bacillus amyloliquefaciens AK-0, a recently isolated bacterium from the rhizospheric soil of Korean ginseng, exerted anti-proliferative activity against human colorectal cancer cells such as HCT116, SW480, LoVo and HT-29 which effectively decreased cyclin D1 protein level in human colorectal cancer cells (Park et al., 2017).

\section{Bacillus cereus}

Bacillus cereus is a Gram-positive, rod shaped, aerobic to facultative, beta hemolytic and soil-dwelling bacterium, one of the causative agents of food poisoning, especially 'Fried rice syndrome' (Bottone, 2010). Bacillus thuringiensis (Bt) is closely related to $B$. cereus but Bt produce unique proteinaceous crystalline proteins, only discriminatory fact between these two bacteria. Many strains of $\mathrm{Bc}$ can function as probiotics providing health benefits to the host when administered in adequate amounts (Araya et al., 2002). Probiotic bacteria are known to produce bioactive substances that exhibit antibacterial, antiviral and anti-tumor properties (Austin, 1989). Probiotic consumption helps the host to maintain intestinal microbial balance, reduce the number of pathogens, improve bowel regularity, restore normal intestinal microbiota and reduce the level of carcinogens (Reid, Jass, Sebulsky, \& McCormick, 2003).

\section{Bacillus cereus (BC1)}

Anticancer metabolites were obtained from an Indian Bacillus cereus strain after successive solvent extraction with petroleum ether, ethyl acetate or methanol (1:1). One of fractions $\mathrm{BC} 1$ showed $\mathrm{CTC}_{50}$ (cytotoxicity $50 \%$ ) values of $225.4 \mu \mathrm{g} / \mathrm{ml}$ against 
Table 1| Molecules obtained from Bacillus spp. with anticancer activity.

\begin{tabular}{|c|c|c|c|c|c|}
\hline Species & Source & Cell lines & $\begin{array}{l}\text { Dosage, } \\
\mathrm{IC}_{50} \\
(\mu \mathrm{g} / \mathrm{ml})^{*}\end{array}$ & Bioactive agents & References \\
\hline $\begin{array}{l}\text { Bacillus } \\
\text { amyloliquefaciens } \\
\text { (MD-bl) }\end{array}$ & $\begin{array}{l}\text { Ophiopogon } \\
\text { japonicas } \\
\text { (medicinal plant) }\end{array}$ & $\begin{array}{l}\text { i. MC-4 } \\
\text { ii. SGC-7901 }\end{array}$ & $\begin{array}{l}\text { i. } 19600 \\
\text { ii. } 26800\end{array}$ & Exopolysaccharide & (C. Li, 2013) \\
\hline Bacillus cereus & Soil & $\begin{array}{l}\text { i.HepG2 } \\
\text { ii. Hep2 }\end{array}$ & $\begin{array}{l}\text { i. } 225.4 \\
\text { ii. } 152.2\end{array}$ & ND & (M. L. V. Kumar et al., 2014) \\
\hline $\begin{array}{l}\text { Bacillus } \quad \text { cereus } \\
\text { SVSK2 }\end{array}$ & Fish & $\begin{array}{l}\text { i. MCF7 } \\
\text { ii. HeLa }\end{array}$ & $\begin{array}{l}\text { i. } 150 \\
\text { ii. } 300\end{array}$ & $\begin{array}{l}\text { Silicic acid, diethyl bis } \\
\text { (trimethylsilyl) ester }\end{array}$ & (Seerangaraj et al., 2017) \\
\hline $\begin{array}{l}\text { Bacillus subtilis } \\
\text { strain FS05 }\end{array}$ & Sponge & $\begin{array}{l}\text { i. HepG2 } \\
\text { ii. HCT } \\
\text { iii. MCF }\end{array}$ & $\begin{array}{l}\text { i. } 10.42 \\
\text { ii. } 4.3 \\
\text { iii. } 75.5\end{array}$ & ND & $\begin{array}{l}\text { (Aboul-Ela, Shreadah, Abdel- } \\
\text { Monem, Yakout, \& Soest, } \\
\text { 2012) }\end{array}$ \\
\hline $\begin{array}{l}\text { Bacillus subtilis } \\
\text { SVSK5 }\end{array}$ & Fish & $\begin{array}{l}\text { i. MCF7 } \\
\text { ii. HeLa }\end{array}$ & $\begin{array}{l}\text { i. } 150 \\
\text { ii. } 300\end{array}$ & $\begin{array}{l}\text { Eicosane, Pentacosane, } \\
\text { Phthalic Acid }\end{array}$ & (Seerangaraj et al., 2017) \\
\hline $\begin{array}{l}\text { Bacillus } \quad \text { subtilis } \\
\text { B1779 }\end{array}$ & Sea water & HeLa & $\begin{array}{l}\text { i. } 33.60 \mu \mathrm{M} \\
\text { ii. } 4.32 \mu \mathrm{M}\end{array}$ & $\begin{array}{l}\text { i. Amicoumacin A } \\
\text { ii. Bacilosarcin B }\end{array}$ & (Y. Li et al., 2012) \\
\hline $\begin{array}{l}\text { Bacillus } \quad \text { subtilis } \\
\text { subsp. subtilis } \mathrm{RG}\end{array}$ & Soil & MCF-7 & 46.64 & ND & $\begin{array}{l}\text { (Ramasubburayan, Sumathi, } \\
\text { Bercy, Immanuel, \& } \\
\text { Palavesam, 2015) }\end{array}$ \\
\hline $\begin{array}{l}\text { Bacillus subtilis } \\
\text { SDNS }\end{array}$ & Sea water & $\begin{array}{l}\text { i. HelaS3 } \\
\text { ii. HepG2 }\end{array}$ & $\begin{array}{l}\text { i. } 77.2 \% \\
\text { ii. } 56.2 \%\end{array}$ & $\varepsilon$-Poly-L-lysine & $\begin{array}{l}\text { (El-sersy, Abdelwahab, \& } \\
\text { Abouelkhiir, 2012) }\end{array}$ \\
\hline $\begin{array}{l}\text { B. subtilis var. } \\
\text { natto } \mathrm{KMD} 1126\end{array}$ & $\begin{array}{l}\text { Natto (fermented } \\
\text { beans) }\end{array}$ & EAC & $10 \%$ & Surfactin & $\begin{array}{l}\text { (Kameda, Matsui, Kato, } \\
\text { Yamada, \& Sagai, 1972) }\end{array}$ \\
\hline $\begin{array}{l}\text { B. subtilis var. } \\
\text { KMD } 2311\end{array}$ & Straw & EAC & $20 \%$ & Surfactin & $\begin{array}{l}\text { (Kameda et al., 1972; Kameda, } \\
\text { Oira, Matsui, Kanatomo, \& } \\
\text { Hase, 1974) }\end{array}$ \\
\hline $\begin{array}{l}\text { Bacillus } \\
\text { licheniformis }\end{array}$ & $\begin{array}{l}\text { Tunisian thermal } \\
\text { source }\end{array}$ & HepG2 & $200 \mathrm{mg} / \mathrm{ml}$ & Levan & $\begin{array}{l}\text { (Dahech, Belghith, Belghith, \& } \\
\text { Mejdoub, 2012) }\end{array}$ \\
\hline $\begin{array}{l}\text { Bacillus } \\
\text { licheniformis } \\
091 D Y M 23\end{array}$ & Marine sediment & $\begin{array}{l}\text { i. NCI-H23 } \\
\text { ii. NUGC3 }\end{array}$ & $\begin{array}{l}\text { i. } 25.18 \\
\text { ii. } 17.78\end{array}$ & Ieodoglucomide B & (Tareq et al., 2013) \\
\hline $\begin{array}{l}\text { Bacillus } \\
\text { licheniformis } \\
\text { RAM-8 }\end{array}$ & Soil & $\begin{array}{l}\text { i. Jurkat clone } \\
\text { E6-1 } \\
\text { ii. MCF-7 } \\
\text { iii. K-562 }\end{array}$ & $\begin{array}{l}\text { i. } 0.22 \mathrm{IU} \\
\text { ii. } 0.78 \mathrm{IU} \\
\text { iii. } \quad 0.153 \\
\text { IU }\end{array}$ & L-asparaginase & (Mahajan et al., 2014) \\
\hline $\begin{array}{l}\text { Bacillus } \\
\text { megaterium } \\
\text { SAmt17 }\end{array}$ & Sea sediments & HepG2 & 218 & EPS & (Abdelnasser et al., 2017) \\
\hline $\begin{array}{l}\text { Bacillus } \\
\text { megaterium ATCC } \\
13368\end{array}$ & & Mel-2 & $0.1-\quad 0.3$ & $\begin{array}{l}\text { Betulinic } \\
\text { metabolites }\end{array}$ & $\begin{array}{l}\text { (Chatterjee, Kouzi, Pezzuto, \& } \\
\text { Hamann, 2000) }\end{array}$ \\
\hline Bacillus flexus & Sea sedimennt & HepG2 & 372 & Exopolysaccharide & (Abdelnasser et al., 2017) \\
\hline Bacillus sp. BS3 & solar salt works & $\begin{array}{l}\text { mammary } \\
\text { epithelial } \\
\text { carcinoma }\end{array}$ & 0.25 & Biosurfactant & $\begin{array}{l}\text { (Makkar, Cameotra, \& Banat, } \\
\text { 2011) }\end{array}$ \\
\hline $\begin{array}{l}\text { Bacillus } \\
\text { safensis } \\
\text { PDRV }\end{array}$ & Sponge & $\begin{array}{l}\text { i. HepG2 } \\
\text { ii. HCT } \\
\text { iii. MCF }\end{array}$ & $\begin{array}{l}\text { i. } 46.9 \\
\text { ii. } 28.6 \\
\text { iii. } 721.3\end{array}$ & ND & (Aboul-Ela et al., 2012) \\
\hline $\begin{array}{l}\text { Bacillus } \\
\text { thuringiensis } \mathrm{S} 13\end{array}$ & Soil & A549 & 133.27 & Exopolymer & $\begin{array}{l}\text { (Parthiban, Vignesh, \& } \\
\text { Thirumurugan, 2014) }\end{array}$ \\
\hline $\begin{array}{l}\text { Bacillus } \\
\text { mojavensis } \\
\text { B0621A }\end{array}$ & $\begin{array}{l}\text { Pinctada } \\
\text { martensii }\end{array}$ & HL-60 & $\begin{array}{l}100 \\
100 \\
1.6 \mathrm{mM}\end{array}$ & $\begin{array}{l}\text { Mojavensin A } \\
\text { iso-C16 fengycin B } \\
\text { Andanteiso-C17 } \\
\text { fengycin B }\end{array}$ & $\begin{array}{l}\text { (Z. Ma, Wang, Hu, \& Wang, } \\
\text { 2012) }\end{array}$ \\
\hline Bacillus silvestris & Crab & $\begin{array}{l}\text { i. BXPC-3 } \\
\text { ii. MCF-7 } \\
\text { iii. SF-268 } \\
\text { iv. NCI-H460 } \\
\text { v. KM20L2 }\end{array}$ & $10^{-4}-10^{-5}$ & Bacillistatins 1 and 2 & (Pettit et al., 2010) \\
\hline $\begin{array}{l}\text { Bacillus } \\
\text { vallismortis BIT- } \\
33\end{array}$ & Seawater & $\begin{array}{l}\text { i. HT-29, } \\
\text { ii. SW } 480 \\
\text { iii. HCT116 }\end{array}$ & 10 & PCC & $\begin{array}{l}\text { (Jeong, Park, Kim, Kim, \& Lee, } \\
\text { 2008) }\end{array}$ \\
\hline $\begin{array}{l}\text { Bacillus } \\
\text { polyfermenticus }\end{array}$ & Probiotic & $\begin{array}{l}\text { i. HT-29 } \\
\text { ii. DLD-1 } \\
\text { iii. Caco-2 }\end{array}$ & $\begin{array}{l}\text { i. } 56 \% \\
\text { ii. } 33 \% \\
\text { iii. } 95 \%\end{array}$ & ND & (Ma, Elise L., Choi et al., 2015) \\
\hline Bacillus sp. $\mathrm{N}$ & Nematode & HeLa & 25 & $\begin{array}{l}\text { 3,5-Dihydroxy-4- } \\
\text { isopropylstilbene }\end{array}$ & (S. N. Kumar et al., 2013) \\
\hline $\begin{array}{l}\text { Marine Bacillus } \\
\text { sp. }\end{array}$ & Sea mud & HCT-116 & $\begin{array}{l}0.68, \quad 1.6 \\
1.3 \mathrm{mg} / \mathrm{ml}\end{array}$ & Mixirins A, B and C & (ZHang, Hua, \& Pei, 2004) \\
\hline $\begin{array}{l}\text { Marine Bacillus } \\
\text { sp. CND-914 }\end{array}$ & Sea sediment & HCT-116 & 0.98 & Halobacillin & $\begin{array}{l}\text { (Trischman, Jensen, \& Fenical, } \\
\text { 1994) }\end{array}$ \\
\hline $\begin{array}{l}\text { Marine Bacillus } \\
\text { sp. BF1-3 }\end{array}$ & Sponge & $\begin{array}{l}\text { i. HepG2 } \\
\text { ii. HCT } \\
\text { iii. MCF-7 }\end{array}$ & $\begin{array}{l}\text { i. } 13.2 \\
\text { ii. } 9.3 \\
\text { iii. } 12.2\end{array}$ & ND & (Aboul-Ela et al., 2012) \\
\hline
\end{tabular}

ND: Not defined; *: Unless stated otherwise

Hep-2 (human laryngeal epithelial carcinoma cell lines). From the mass spectroscopic analysis of TLC fractions of BC1, it was revealed that the fraction was devoid of any proteins (Kumar et al, 2014).

\section{Bacillus cereus SVSK2}

Bacillus cereus SVSK2, a probiotic bacteria, isolated from Oreochromis mossambicu (Seerangaraja et al., 2017) whose cell free extracts exerted significant cytotoxicity on human cervical cancer cell line (HeLa) and breast cancer cell line (MCF-7) with $\mathrm{IC}_{50}$ of 150 $\mu \mathrm{g} / \mathrm{ml}$ and $300 \mu \mathrm{g} / \mathrm{ml}$ respectively in MTT assay showing reduced growth and disrupted cell wall indicating apoptosis. Gas Chromatography Mass Spectrometry (GC-MS) results revealed that this strain contained Silicic acid, diethyl bis (trimethylsilyl) ester along with other metabolites which had anticancer property (Seerangaraja et al., 2017).

\section{Bacillus subtilis}

Bacillus subtilis, an inhabitant of the upper layers of the soil, is a rod-shaped Gram-positive spore forming bacterium and capable of growing in minimal nutritional conditions (Piggot, 2009; van Dijl \& Hecker, 2013). In such conditions, $B$. subtilis can undergo a series of responses including synthesis of antibiotics and extracellular enzymes, competence to take up DNA, motility and biofilm formation (Piggot, 2009). Many of the $B$. subtilis strains isolated from different regions with anticancer properties are discussed below.

\section{Bacillus subtilis strain FS05}

Crude extracts of Bacillus subtilis strain FS05, isolated from Red sea sponge Amphimedon ochracea, showed cytotoxicity against three established human cancer cell lines; HepG2 (hepatocellular carcinoma), HCT (colon carcinoma) and MCF-7 (breast carcinoma) with an $\mathrm{IC}_{50}$ of $10.42,4.3$ and $5.5 \mu \mathrm{g} / \mathrm{ml}$ respectively following MTT assay (Aboul-Ela et al., 2012).

\section{Bacillus subtilis SVSK5}

Bacillus subtilis strain SVSK5 isolated from the gastro-intestinal tract of fish (Labeo rohita) was found to express Eicosane, Pentacosane, Phthalic acid etc. These compounds altogether exhibited cytotoxicity against MCF-7 and HeLa cells at 150 $\mu \mathrm{g} / \mathrm{ml}$ and $300 \mu \mathrm{g} / \mathrm{ml}$ respectively in MTT assay (Seerangaraja et al., 2017).

\section{Bacillus subtilis B1779}

A red sea bacterium, B. subtilis strain B1779 expressed 11 amicoumacins, including four novel lipoamicoumacins (type A- D) and a new Bacilosarcin C (Supplementary Fig. 1). Amicoumacin A and bacilosarcin B exhibited cytotoxicity against the HeLa cells with $\mathrm{IC}_{50}$ values of 33.60 and $4.32 \mu \mathrm{M}$ respectively as revealed upon MTT assay. An amide functional group at C-12' might have played a critical role in the mentioned cytotoxicity (Y. Li et al., 2012). 


\section{Bacillus subtilis subsp. subtilis RG}

Crude extract of $B$. subtilis subsp. subtilis RG, isolated from the rhizospheric soil of a mangrove plant species, Excoecaria agallocha at South east coast of India, exerted significant cytotoxicity against MCF-7 (Human breast adenocarcinoma). The $\mathrm{IC}_{50}$ value was $46.64 \pm 0.79 \mu \mathrm{g} / \mathrm{ml}$ as determined through MTT assay. MCF-7 cells, due to the unidentified compound from Bss RG, were subjected to morphological abnormalities i.e. cell shrinkage, membrane blebbing, loss of integrity and cell adhesion properties which indicated the occurrence of apoptosis (Ramasubburayan et al., 2015).

\section{Bacillus subtilis SDNS}

The culture supernatant of a marine Bacillus subtilis strain SDNS isolated from Alexandria, Egypt, was investigated against HeLa S3 (human cervix adenocarcinoma cell line), Hep G2 (Human hepatocellular liver carcinoma cell line) and $\mathrm{CaCo} 2$ (Human colonic carcinoma cell line) for cytotoxicity. Following MTT assay, highest cytotoxicity was observed against Hela S3 (77.2\% inhibition) followed by Hep G2 (56.2\% inhibition) and almost no cytotoxicity was observed towards $\mathrm{CaCo} 2$. The compound responsible for this toxicity was $\varepsilon$-Poly-L-lysine ( $\varepsilon$-PL) (El-sersy et al., 2012) which is basically a homopolymer with antimicrobial and anti-tumor activity (Szende et al., 2002).

\section{B. subtilis var. natto}

B. subtilis var. natto (Bn), previously known as Bacillus natto, was isolated from Natto, a type of fermented beans and straws. Bn KMD 1126 (Kameda et al., 1972) and KMD 2311 (Kameda et al., 1974) synthesized two types of cytolytic compounds respectively and exhibited mild cytolytic activities (10\% and $20 \%$ respectively) against Ehrlich ascites carcinoma cells. The Bn KMD 1126 derived surfactin like compound was stable in a wide range of $\mathrm{pH}$ and temperature whereas KMD 2311 derived cytolytic compounds were more stable colorless crystalline one with melting point of $247-249^{\circ} \mathrm{C}$ which were identical with surfactin and dimorphic.

Although the surfactin produced by Bacillus sp. along with other organisms has mainly antifungal and antibacterial properties, it demonstrated antitumor activity (Gudina, Rangarajan, \& Sen, 2013) and cancer cells killing ability through cell cycle arrest and apoptosis (Meena et al., 2017).

\section{Bacillus licheniformis}

Bacillus licheniformis, a mesophilic spore-former commonly found in soil and bird feathers (Veith et al., 2004) is part of the subtilis group along with Bacillus subtilis and Bacillus pumilus. Though B. licheniformis possess similar (about 80\%) coding sequence to $B$. subtilis, the amount and location of prophages, transposable elements, extracellular enzymes, and secondary metabolic pathway operons make it different from B. subtilis (Rey et al., 2004). This bacterium is industrially important because of its ability to produce a range of extracellular enzymes, especially proteases. Due to their activity at high $\mathrm{pH}$ and thermostability, proteases from this bacteria became an useful ingredient in laundry detergent which prevents shrinkage and fading of colors (D. Kumar et al., 2008). Apart from this, keratinase produced by $B$. licheniformis is used in leather industry as dehairing agent as well as in feed industry for feather digestion (Hoq et al., 2005; Lin et al., 1992; Tiwary \& Gupta, 2010). Protease and keratinase were also expressed in heterologous expression system through recombinant DNA technology in several occasions for easy and feasible downstream processing (Jacobs, Eliasson, Uhlén, \& Flock, 1985; Nahar et al., 2016; Radha \& Gunasekaran, 2007; Sareen, Bornscheuer, \& Mishra, 2005; Tang et al., 2004). B. licheniformis produces bacitracin and also used as probiotic (Azarin, Aramli, Imanpour, \& Rajabpour, 2014; Haavik, 1979).

\section{Bacillus licheniformis sp. (Levan producing)}

B. licheniformis reported by Dahech et al. catalyzes the formation of fructo-oligosaccharides and the synthesis of Levan polymers, a larger group of commercially important polymers which is a source of prebiotic fibre (Dahech et al., 2012; Franken, Brandt, Tai, \& Bauer, 2013; GMT, Lima, de Franca, \& Lopes, 2000; Kim et al., 2005; Yoo, Yoon, Cha, \& Lee, 2004). Levan showed in vitro cytotoxicity against HepG2 cells (highest at $200 \mathrm{mg} / \mathrm{ml}$ ) when applied in a dose-dependent manner whereas no effect was observed against WRL68 (Human fetal liver) cells (Dahech et al., 2012).

\section{Bacillus licheniformis 09IDYM23:}

Bacillus licheniformis strain 09IDYM23 was isolated from marine sediment sample collected from Ieodo, southern reef of Korea with high salinity and alkaline $\mathrm{pH}$. This bacterium produced two unique glycolipopeptides such as Ieodoglucomides A and B, containing a new fatty acid unit, 14-hydroxy-15-methylhexadecanoic acid (HMA). Ieodoglucomide B (Supplementary Fig. 2) exhibited cytotoxicity against lung cancer NCI-H23 and stomach cancer cell lines (NUGC-3) with $\mathrm{GI}_{50}$ (growth inhibition) values of 25.18 and $17.78 \mu \mathrm{g} / \mathrm{mL}$ respectively in sulforhodamine B (SBR) assay (Tareq et al., 2013).

\section{Bacillus licheniformis RAM-8}

B. licheniformis RAM-8 produced an extracellular L- asparaginase enzyme (MW- $134.8 \mathrm{kDa}$ ) with low glutaminase activity which is a therapeutic agent to treat the malignancies of lymphoid system, acute lymphoblastic leukemia, non- Hodgkin's lymphoma etc. (Gallagher, Marshall, \& Wilson, 1989; Mahajan et al., 2014). L- asparaginase hydrolyses the L-asparagine, obtained from exogenous sources and on which the leukemic cells depend, into L-aspartic acid and ammonia in blood vascular system causing its depletion and inhibiting protein synthesis of leukemic cells leading to their apoptosis (Mashburn \& Wriston, 1963; Mccredie, Ho, \& EmilJ. Freireich, 1953). L- asparaginase from B. licheni- 
formis RAM-8 was found to be functionally stable and active over a wide range of $\mathrm{pH}$ and temperature and the cytotoxicity was observed against Jurkat clone E6-1, MCF-7 and K-562 cell lines with $\mathrm{IC}_{50}$ of $0.22 \mathrm{IU}, 0.78 \mathrm{IU}$ and $0.153 \mathrm{IU}$ respectively. The enzyme was reported to be free of any toxic effect on human erythrocytes and CHO cell lines (Mahajan et al., 2014).

\section{Bacillus megaterium}

Bacillus megaterium $(\mathrm{Bm})$ is a Gram-positive spore forming bacterium and the key distinguishing feature of this bacterium from other Bacillus spp. is its immense size. This bacterium is the largest of all bacilli. Generally, most of the genome sequence of Bacillus spp. are closely related to B. cereus or B. subtilis but Bm is the only distantly related to B. cereus or B. subtilis (Eppinger et al., 2011; Porwal et al., 2009). Bm is the one of the first bacterial genome that has been fully coded and is frequently used as nonpathogenic host for the biotechnological production of a wide variety of substances like Vitamin B12, penicillin acylase, amylases and many more (Eppinger et al., 2011).

Bm SAmt17, isolated from the Mediterranean sea, produced a low molecular weight exopolysaccharide, EPS-6 (4.296×104 g/ mol) which demonstrated cytotoxicity ( $\mathrm{IC}_{50}$ of $218 \mu \mathrm{g} / \mathrm{ml}$ ) against HepG2 cells due to the presence of sulfur (46\%) and uronic acids (Abdelnasser et al., 2017).

During the biotransformation of betulinic acid by Bm ATCC 13368 , it produced four cytotoxic compounds namely 3-oxo-lup-20(29) en-28-oic acid, 3-oxo-11a-hydroxy-lup-20(29)-en-28-oic acid, 1b-hydroxy-3-oxo-lup-20(29)-en-28-oic acid and 3b,7b,15a-trihydroxy-lup-20(29)-en-28-oic acid. The first three compounds showed antimelanoma activity against human melanoma cell lines Mel-2 with an $\mathrm{ED}_{50}$ of $0.1,0.2$ and $0.3(\mu \mathrm{g} / \mathrm{ml})$ respectively (Chatterjee et al., 2000). Beside the anticancer activity of betulinic acid metabolites, betulinic acid has also anti-tumor activity against different type of cancer cells including human melanoma (Pisha et al., 1995).

\section{Bacillus flexus}

Bacillus flexus (SAmt74) produced a low molecular weight exopolysaccharide, EPS-7 $(3.756 \times 104 \mathrm{~g} / \mathrm{mol})$ which showed significant cytotoxicity $\left(\mathrm{IC}_{50^{-}}-372 \mu \mathrm{g} / \mathrm{ml}\right)$ against HepG2 cells having 24\% sulfur content (Abdelnasser et al., 2017).

\section{Bacillus sp. BS3}

A halophilic Bacillus sp. BS3, isolated from solar salt works, produced biosurfactants such as 3- Docosenamide, Mannosamine, 9- Octadecenamide, 2- Octanol, 2- methyl- 6methylene, Cylohex- 1, 4, 5- triol- 3- one- 1- carbo and 1, 2Ethanediamine, N, N, N', N'- tetramethyl-which showed varied cytotoxicities (maximum 24.8\%) against mammary epithelial carcinoma cells (Donio et al., 2013). Microorganism derived biosurfactants could be glycolipids, lipopeptides, lipopolysaccharides, polysaccharide- protein complexes, fatty acids and lipids
(Makkar et al., 2011) with enormous applications in therapeutic and biomedical fields such as antibacterial, antifungal, antiviral, anticancer, immunomodulator, anti-adhesive, antioxidants, dermal fibroblasts stimulant, vaccines and gene therapy (Bhadoriya \& Madoriya, 2013; Gudina et al., 2013).

\section{Bacillus safensis strain PDRV}

Crude extracts of Bacillus safensis strain PDRV, isolated from Red sea sponge Amphimedon ochracea, showed cytotoxicity against three established human cancer cell lines; HepG2 (hepatocellular carcinoma), HCT (colon carcinoma) and MCF-7 (breast carcinoma) with $\mathrm{IC}_{50}$ of $46.9,28.6$ and $21.3 \mu \mathrm{g} / \mathrm{ml}$, respectively following MTT assay (Aboul-Ela et al., 2012).

\section{Bacillus thuringiensis}

Bacillus thuringiensis (Bt) synthesizes $\delta$ - endotoxins (Cry, Cyt or parasporin proteins) in its parasporal body during sporulation which was reported for antitumor effects and unique activity specifically against cancer cells (Mizuki et al., 1999; Prasad \& Shethna, 1974) besides long history and application as biopesticide for larvicidal activity. The toxicity of the parasporins were reported against various cancer cells such as MOLT-4, HeLa, HepG2, JURKAT, HL60, TCS, CACO-2 etc (Table 2) upon their proteolytic activation (Mizuki et al., 1999) with non-toxicity against normal cell lines (S. Okumura et al., 2010). To date, 19 parasporins were discovered and categorized into 6 major classes (PS1- PS6) (S. Okumura et al., 2010) and few other parasporin like proteins are yet to be classified (Poornima et al., 2010; Gonzalez et al., 2011; Ammons et al., 2016). Among these six classes of parasporin, only PS1 kills cancer cells by activating apoptotic signaling pathway causing from attenuation of cellular protein and DNA synthesis, and by increasing influx of calcium ions (Katayama et al.,2007). It was reported that parasporin-1 could bind to the receptor Beclin 1 in the cell membrane (Katayama et al.,2007; $\mathrm{Xu}$, Wang, \& Yu, Ziniu and Sun, 2014). In case of parasporin 2, it accumulates in lipid rafts on target cell surfaces through interaction with a putative proteinaceous receptor which gets associated with the glycan core of GPI-anchored proteins for stability. PS2 subsequently forms a membrane embedded oligomer that forms pore and induces permeability of the plasma membrane leading to cell death (Abe et al., 2017). Other PS proteins also kill cells by pore formation.

\section{Bacillus thuringiensis S13}

Bacillus thuringiensis S13, found in the coastal soil samples, produced anti-proliferative exopolymer which inhibited lung cancer cell line (A549) with an $\mathrm{IC}_{50}$ of $133.27 \mu \mathrm{g} / \mathrm{ml}$ as detected using XTT assay. FTIR spectra of exopolymer revealed that a brominated compound 1,1,3,1"-Terphenyl,3,3,5,5-tetrabromo-5-(3,5-dibromophenyl) was present in the exopolymer that could be responsible for cytotoxicity (Parthiban et al., 2014).

\section{Bacillus mojavensis B0621A}

Bacillus mojavensis B0621A, isolated from Pinctada martensii 
Table 2 | Cytotoxicity spectrums of parasporins. The levels of cytotoxicity, based on $\mathrm{EC}_{50}$ as estimated using cell proliferation assays, are denoted as follows: extremely high, ++++; high, +++; moderate, ++; low, + and non- toxic, -; NT, indicates not tested (Ekino et al., 2014; Ito et al., 2004; Katayama et al., 2005; Nagamatsu, Okamura, Saitou, Akao, \& Mizuki, 2010; Shiro Okumura, Saitoh, Ishikawa, Inouye, \& Mizuki, 2011; Yamashita et al., 2005).

\begin{tabular}{|c|c|c|c|c|c|c|c|c|}
\hline Cell line & Origin & Name & PS1 & PS2 & PS3 & PS4 & PS5 & PS6 \\
\hline MOLT 4 & \multirow[t]{14}{*}{ Human } & Leukemic T cell & ++ & ++++ & - & - & ++++ & - \\
\hline JURKAT & & Leukemic T cell & - & ++++ & - & - & +++ & - \\
\hline HL60 & & Myeloid Leukemia & +++ & ++++ & ++ & +++ & ++ & NT \\
\hline HeLa & & Uterus cervix cancer & +++ & - & - & - & t+++ & + \\
\hline TCS & & Uterus cervix cancer & - & - & - & - & ++++ & NT \\
\hline Sawano & & Uterus cancer & - & ++++ & - & - & ++++ & NT \\
\hline HepG2 & & Hepatocyte cancer & ++ & ++++ & ++ & ++ & ++++ & ++++ 1090 \\
\hline A549 & & Lung cancer & - & +++ & - & - & + & NT \\
\hline CACO-2 & & Colon cancer & - & + & - & - & +++ & + \\
\hline $\mathrm{T}$ cell & & Normal T cell & - & +++ & - & - & - & NT \\
\hline UtSMC & & Normal uterus & - & ++ & - & - & ++ & NT \\
\hline $\mathrm{HC}$ & & Normal Hepatocyte & - & - & - & - & - & - \\
\hline MRC-5 & & Normal Lung & - & + & - & - & ++ & NT \\
\hline K562 & & Myelogenous leukemia & NT & NT & NT & + & + & NT \\
\hline Vero & Monkey & Monkey Kidney & - & NT & - & - & ++++ & NT \\
\hline $\cos -7$ & & Monkey Kidney & - & - & - & - & ++++ & NT \\
\hline PC12 & Rodent & Pheochromocytoma & NT & NT & NT & ++ & NT & NT \\
\hline $\mathrm{CHO}$ & & Ovary cell & - & ++++ & - & + & ++ & NT \\
\hline NIH3T3 & & Embryo cell & - & ++++ & - & + & ++ & NT \\
\hline
\end{tabular}

(Pearl Oyster) in the South China Sea, exerted three iturinic lipopeptides that were isolated by bioactivity-guided fractionation. They were identified as Mojavensin A (Supplementary Fig. 3), iso-C16 fengycin B and anteiso-C17 fengycin B and inhibited the growth of human leukemia cell line HL-60 with $\mathrm{IC}_{50}$ of 100 , 100 and $1.6 \mathrm{mM}$, respectively as revealed in MTT assay (Z. Ma et al., 2012).

\section{Bacillus silvestris}

Bacillus silvestris isolated from a Pacific Ocean (southern Chile) crab, produced bacillistatins 1 (Supplementary Fig. 4) and 2 which strongly inhibited the growth of human cancer cell lines including Human pancreas (BXPC-3), breast (MCF-7), CNS (SF-268), lung (NCI-H460), colon (KM20L2), prostate (DU-145) etc with $\mathrm{GI}_{50}$ of 10-4-10-5 $\mu \mathrm{g} / \mathrm{mL}$ (Pettit et al., 2010).

\section{Bacillus vallismortis BIT-33}

Bacillus vallismortis BIT-33 produced a secondary metabolite, PCC which exerted cytotoxic effects on HT-29, SW480 and HCT116 cells. It was soluble in methanol $(\mathrm{MeOH})$, ethanol (EtOH), acetonitrile $\left(\mathrm{CH}_{3} \mathrm{CN}\right)$, dichloromethane $\left(\mathrm{CH}_{2} \mathrm{Cl}_{2}\right)$ and ethyl acetate (EtOAc) whereas insoluble in hexane and water. PCC demonstrated anticancer cell activity with a concentration of $10 \mu \mathrm{g} / \mathrm{ml}$ where cell viability was about $40 \%$ causing apoptosis of cells in a dose- and time-dependent manner (Jeong et al., 2008).

\section{Bacillus polyfermenticus}

Bacillus polyfermenticusis a probiotic bacterium which was first found in the air by Dr. Terakado (1933) and was used in the treatment of intestinal disorders (Lee, Park, Park, \& Paik, 2007; E. L. Ma et al., 2010). Probiotic bacteria exert anticancer properties through improvement of normal intestinal microbiota, immune modulation, degradation of potential mutagens and enhancement of local and systemic antioxidant activity (Reid et al., 2003; Yu \& Li, 2016).

Bacillus polyfermenticus SCD showed cytotoxicity against colon cancer cells, Caco-2 in a dose dependent manner. After 72 hours of treatment, growth of Caco-2 cells was inhibited 24.6\%, 20.3\%, $37.1 \%$ and $42.2 \%$ with $B$. polyfermenticus SCD concentration at 100, 500, 1000 and $2000 \mu \mathrm{g} / \mathrm{ml}$, respectively (Lee et al., 2007). Conditioned medium for B. polyfermenticus (B.P. CM), containing heat stable bacterial protein, inhibited the growth of human colon cancer cells HT-29 (35\% - 56\%), DLD-1 (69\% - 33\%), and Caco-2 (99\% - 95\%) when treated for 7- 14 days respectively (Ma et al. 2015). B.P. CM reduced the mRNA level expression for ErbB2 and ErbB3 receptors, critical players in colon cancer development, followed by reduction of expression of cell cycle regulator cyclin D1 and its transcriptional regulator E2F-1 that significantly block ErbB- dependent tumorigenesis. It was suggested that B.P. CM possess heat stable proteins of molecular weight $>30 \mathrm{kDa}$, either lipopolysaccharide (LPS) or flagellin, responsible for in vitro suppression of cancer cell growth and in vivo suppression of tumor growth due to the anti-proliferative, anti-tumorigenic and anti-angiogenic properties (E. L. Ma et al., 2010).

\section{Bacillus sp. N}

Bacillus sp. N, associated with rhabditid entomopathogenic nematode, produced 3,5-Dihydroxy-4-isopropylstilbene (DHPS) which was first identified as bacterial secondary metabolite in spite of being a phytoalexin and DHPS showed cytotoxicity against breast cancer (MDAM B-231), cervical cancer (HeLa), lung cancer (A 549), colon cancer cells but found to be sensitive against $\mathrm{HeLa}$ cells line with an $\mathrm{IC}_{50}$ of $25 \mu \mathrm{g} / \mathrm{ml}$ using MTT assay. It induced significant morphological changes like chromatin condensation and blebbing and DNA fragmentation with increased Caspase 3 activity indicating apoptosis in HeLa cells (Kumar et al., 2013).

\section{Marine Bacillus sp.}

Bacillus sp., isolated from sea mud near the Arctic pole, produced three new cyclopeptides belonging to iturin class named as mixirins A, B and C. Mixirins A, B and C inhibited the growth of human colon cancer cells (HCT-116) with IC50 of 0.68, 1.6, 1.3 $\mathrm{mg} / \mathrm{ml}$, respectively (ZHang et al., 2004). Lipopeptides like iturin was reported to be cytotoxic against different cancer cells ( Dey et al., 2016).

Bacillus species, isolate CND-914, obtained from a marine sediment core near the Guaymas Basin in Mexico, produced 


\section{REVIEWS}

\section{Table 3| Mode of actions of different microbial bioactive} agents

\begin{tabular}{|c|c|c|}
\hline $\begin{array}{l}\text { Associated bioactive } \\
\text { agents }\end{array}$ & Mode of action & References \\
\hline Exopolysaccharide & $\begin{array}{l}\text { Cause morphological abnormalities and } \\
\text { mitochondrial dysfunction in tumor cells leading to } \\
\text { apoptosis }\end{array}$ & (Chen et al., 2013) \\
\hline Amicoumacin A & Inhibit mRNA translation & (Prokhorova et al., 2016) \\
\hline$\varepsilon$-Poly-L-lysine & Cause morphological changes and growth inhibition & $\begin{array}{l}\text { (Arnold, Dagan, Gutheil, } \\
\text { \& Kaplan, 1979) }\end{array}$ \\
\hline Surfactin & $\begin{array}{l}\text { Inhibit tumor growth, cell cycle arrest, apoptosis and } \\
\text { metastasis arrest }\end{array}$ & (Wu et al., 2017) \\
\hline Levan & Increase oxidative stress and apoptosis & (Queiroz et al., 2017) \\
\hline L-asparaginase & $\begin{array}{l}\text { Causes nutritional deficiencies and inhibit protein } \\
\text { synthesis resulting in apoptosis }\end{array}$ & (Shrivastava et al., 2016) \\
\hline Ieodoglucomide B & Inhibit tumor cell growth & (Tareq et al., 2013) \\
\hline Bacillistatins 1 and 2 & Inhibit tumor cell growth & $\begin{array}{l}\text { (Pettit, Arce, Chapuis, \& } \\
\text { Macdonald, 2015) }\end{array}$ \\
\hline Mixirins A, B and C & Inhibit tumor cell growth & (Harris \& Pierpoint, 2012) \\
\hline Parasporin 1 & $\begin{array}{l}\text { Activates apoptotic signaling pathway by binding with } \\
\text { Beclin } 1 \text { receptor and increase } \mathrm{Ca}^{2+} \text { influx }\end{array}$ & (Katayama et al., 2007) \\
\hline Parasporin 2 & $\begin{array}{l}\text { Permeabilize plasma membrane through GPI- } \\
\text { anchored protein }\end{array}$ & (Abe et al., 2017) \\
\hline Parasporin 3 & Pore formation & (Ito et al., 2004) \\
\hline Parasporin 4 & Cholesterol independent pore formation & (Yamashita et al., 2005) \\
\hline Parasporin 6 & Swelling of cells and vacuoles formation & (Nagamatsu et al., 2010) \\
\hline
\end{tabular}

halobacillin which is a novel cyclic acylpeptide of the iturin class, reported to be produced by a marine isolate for the first time. Halobacillin showed moderate human cancer cell cytotoxicity on Human colon cancer cell line HCT116 with an $\mathrm{IC}_{50}$ of $0.98 \mu \mathrm{g} / \mathrm{ml}$. Halobacillin is similar to surfactin but the major difference is the replacement of the glutamic acid of surfactin with a glutamine in halobacillin (Jacqueline et al., 1994).

Bacillus sp BF1-3 was isolated from Red sea sponge Amphimedon ochracea. Crude extracts of bacterial culture showed cytotoxicity against HepG2 (hepatocellular carcinoma), HCT (colon carcinoma) and MCF-7 (breast carcinoma) with an $\mathrm{IC}_{50}$ of 13.2, 9.3 and $12.2 \mu \mathrm{g} / \mathrm{ml}$, respectively as estimated using MTT assay (Aboul-Ela et al., 2012).

\section{Clinical trials and animal model experiments Bacillus oligonitrophilus KU-1}

Bacillus oligonitrophilus KU-1, a gram positive and spore forming bacteria, was isolated from soil of Kazan city, Russia. Stationary phase culture of this bacterium at a concentration of $0.5-1.0 \times 10^{9}$ cells $/ \mathrm{ml}$ was used for cancer treatment after testing toxicity and genotoxicity using Ames test. Culture was administered orally to 13 patients suffering from different types of adenocarcinoma and other forms of carcinoma (tumor in colon, ovary, backbone and maxillary sinus) with varied doses of 2.5- $200 \mathrm{ml}$ (day 1- day 13) at different time intervals. The bacterial treatment showed oncomarker reduction in every patient and life prolongation more than the standard prognosis with minimal side effects. Malkov et al. suggested Bacillus oligonitrophilus $\mathrm{KU}-1$ as an effective probiotic and promising anticancer agent which successfully block highly differentiated and mildly differentiated mammary gland adenocarcinoma with metastases into bones and lymph nodes. Presence of silicon was attributed to the death of tumor cells in case of this silicate bacteria (Malkov, Markelov, Polozov, \& Sobchuk, 2005).

\section{Bacillus thuringiensis}

Parasporin- 4 (PS4), an aerolysin- type $\beta$-pore-forming toxin from Bacillus thuringiensis strain A1470 produced upon proteolytic activation (Shiro Okumura et al., 2011) was examined in mice model if this promising anticancer protein could be used in cancer therapy (Shiro Okumura, Koga, Inouye, \& Mizuki, 2014). In ICR mice (a strain of albino mice sent from the Institute of Cancer Research in the USA), the $\mathrm{LD}_{50}$ value was determined as $160 \mu \mathrm{g} / \mathrm{kg}$ with the reduction of potassium, ammonium, magnesium ion, creatinine and urea nitrogen in urine and increased creatinine and urea nitrogen in mice serum that impaired kidney function. Upon oral administration of Pro- PS4 (10 mg dry wt/200 $\mu \mathrm{L}$ D.W.) in C57BL/6J mice thrice in a week for 40 days, no serious health hazard was observed (Shiro Okumura et al., 2014).

\section{Bacillus polyfermenticus}

Probiotic bacterium Bacillus polyfermenticus (B.P) produced strong cytotoxic effect against various cancer cell lines including colon, breast, cervical and lung cancers. Anti-cancer effect of B.P. was reported as detected in vivo using the mouse xenograft model of human colon cancer which caused the reduction in tumor size and weight by suppressing cell proliferation and angiogenesis. It was suggested that in Bacillus polyfermenticus due to the reduction of ErbB2 and ErbB3 expression, the E2F-1 and cyclin D1 expression is down-regulated in tumor cells leading to the inhibition of tumor growth (Ma et al. 2015).

\section{Conclusion}

If identified at early stage, cancer is more likely to respond to effective treatments and can result in less morbidity and less expenses. Bacillus spp. produce two major lipopeptides i.e. surfactin and iturins besides other unique metabolites like mojavensin, bacillistatins, $\varepsilon$-poly-L-lysine, halobacillin, PCC and EPS etc. which exhibited toxicity against cancer cells. Nevertheless, many of these bioactive agents were not examined in vivo, e.g. in rodents, which is a major shortcoming of these metabolites to be used in preliminary cancer therapy (Burger \& Fiebig, 2004). Moreover, although the crude extracts or conditioned medium of some Bacillus sp. showed cytotoxicity to cancer cells, the specific active compounds are still unidentified. Further investigation in search of those active metabolites as well as in vivo study would be helpful in developing new anticancer drug from Bacillus species for a sustainable and economic cancer treatment process. 


\section{Author contribution}

UTF drafted the manuscript. MAS guided the composition and revised it. SNK and MMH did meticulous review and finalized it. Acknowledgement

The authors do not declare acknowledge in this article.

\section{Competing financial interests}

The authors declare no conflict of interest.

\section{References}

Abdelnasser, S. M., Yahya, S. M. M., Mohamed, W. F., Asker, M. S., Shady, H. M. A., Mahmoud, M. G., \& Gadallah, M. A. (2017). Antitumor Exopolysaccharides Derived from Novel Marine Bacillus $\bigotimes$ : Isolation, Characterization Aspect and Biological Activity. Asian Pac J Cancer Prev, 18(7), 1847-1854. https://doi.org/10.22034/APJCP.2017.18.7.1847

Abe, Y., Inoue, H., Ashida, H., Maeda, Y., Kinoshita, T., \& Kitada, S. (2017). Glycan region of GPI anchored-protein is required for cytocidal oligomerization of an anticancer parasporin-2, Cry46Aa1 protein, from Bacillus thuringiensis strain A1547. Journal of Invertebrate Pathology, 142, 71-81. https://doi.org/10.1016/j.jip.2016.11.008 Aboul-Ela, H. M., Shreadah, M. A., Abdel-Monem, N. M., Yakout, G. A., \& Soest, R. W. M. van. (2012). Isolation, cytotoxic activity and phylogenetic analysis of Bacillus sp. bacteria associated with the red sea sponge Amphimedon ochracea. Advances in

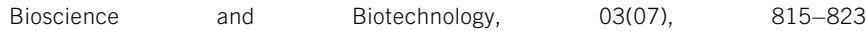
https://doi.org/10.4236/abb.2012.37101

Adams, G. P., \& Weiner, L. M. (2005). Monoclonal antibody therapy of cancer. Nature Biotechnology, 23(9), 1147-1157. https://doi.org/10.1038/nbt1137

Ammons, D. R., Short, J. D., Bailey, J., Hinojosa, G., Tavarez, L., Salazar, M., \& Rampersad, J. N. (2016). Anti-cancer Parasporin Toxins are Associated with Different Environments: Discovery of Two Novel Parasporin 5-like Genes. Current Microbiology. https://doi.org/10.1007/s00284-015-0934-3

Amran, N. (2017). Undertsanding cancer for non-technical pupils. Journal of Angiother apy, 1(1), E039-E040. https://doi.org/10.25163/angiotherapy.11000951108100517 Araya, M., Morelli, L., Reid, G., Sanders, M. E., Stanton, C., Pineiro, M., \& Ben Embarek, P. (2002). Guidelines for the Evaluation of Probiotics in Food. Joint FAO/WHO Working Group Report on Drafting Guidelines for the Evaluation of Probiotics in Food, 1-11. https://doi.org/10.1111/j.1469-0691.2012.03873

Arnold, L. J., Dagan, A., Gutheil, J., \& Kaplan, N. O. (1979). Antineoplastic activity of poly(L-lysine) with some ascites tumor cells. Proceedings of the National Academy of Sciences, 76(7), 3246-3250. https://doi.org/10.1073/pnas.76.7.3246

Aslam, M. S., Naveed, S., Ahmed, A., Abbas, Z., Gull, I., \& Athar, M. A. (2014). Side Effects of Chemotherapy in Cancer Patients and Evaluation of Patients Opinion about Starvation Based Differential Chemotherapy. Journal of Cancer Therapy, 05(08), 817-822. https://doi.org/10.4236/jct.2014.58089

Austin, B. (1989). Novel pharmaceutical compounds from marine bacteria. Journal of Applied Bacteriology, 67, 461-470

Azarin, H., Aramli, M. S., Imanpour, M. R., \& Rajabpour, M. (2014). Effect of a Probiotic Containing Bacillus licheniformis and Bacillus subtilis and Ferroin Solution on Growth Performance, Body Composition and Haematological Parameters in Kutum (Rutilus frisii kutum) Fry. Probiotics and Antimicrobial Proteins, 7(1), 31-37. https://doi.org/10.1007/s12602-014-9180-4
Baruzzi, F., Quintieri, L., Morea, M., \& Caputo, L. (2011). Antimicrobial compounds produced by Bacillus spp . and applications in food. Science against Microbial Pathogens: Communicating Current Research and Technological Advances, $1102-1111$

Bérdy, J. (2005). Bioactive Microbial Metabolites. The Journal of Antibiotics, 58(1), 1-26. https://doi.org/10.1038/ja.2005.1

Bhadoriya, S. S., Madoriya, N., Shukla, K., \& Ms, P. (2013). A New Pharmaceutical Additive for Solubility Enhancement and Pharmaceutical Development. Biochemistry \& Pharmacology, 2(2). https://doi.org/10.4172/2167-0501.1000113

Bhanot, A., Sharma, R., \& Noolvi, M. N. (2011). Natural sources as potential anti-cancer agents: A review. International Journal of Phytomedicine, 3(1), 09-26. https://doi.org/10.5138/ijpm.v3i1.278

Blunt, J. W., Copp, B. R., Hu, W., Munro, M. H. G., \& Northcote, T. (2008). Marine natural products. Nat. Prod. Rep, 25, 35-94. https://doi.org/10.1039/b701534h

Bottone, E. J. (2010). Bacillus cereus, a volatile human pathogen. Clinical Microbiology Reviews, 23(2), 382-398. https://doi.org/10.1128/CMR.00073-09

Burger, A. M., \& Fiebig, H.-H. (2004). Preclinical Screening for New Anticancer Agents. Handbook of Anticancer Pharmacokinetics and Pharmacodynamics, W. D. Figg(Humana Press Inc., Totowa, NJ), 29-44.

Chatterjee, P., Kouzi, S. A., Pezzuto, J. M., \& Hamann, M. T. (2000). Biotransformation of the Antimelanoma Agent Betulinic Acid by Bacillus megaterium ATCC 13368. Applied and Environmental Microbiology, 66(9), 3850-3855.

Chen, Y.-T., Yuan, Q., Shan, L.-T., Lin, M.-A., Cheng, D.-Q., \& Li, C.-Y. (2013). Antitumor activity of bacterial exopolysaccharides from the endophyte Bacillus amyloliquefaciens sp. isolated from Ophiopogon japonicus. Oncology Letters, 5(6), 1787-1792. https://doi.org/10.3892/ol.2013.1284

Chew, Y. L., Lim, Y. Y., Omar, M., \& Khoo, K. S. (2008). Antioxidant activity of three edible seaweeds from two areas in South East Asia. LWT, 41, 1067-1072. https://doi.org/10.1016/j.Iwt.2007.06.013

Clayson, D. B., Mehta, R., \& Iverson, F. (1994). Oxidative DNA damage - - The effects of certain genotoxic and operationally non-genotoxic carcinogens. Mutation Research, $317,25-42$

Dahech, I., Belghith, K. S., Belghith, H., \& Mejdoub, H. (2012). Partial purification of a Bacillus licheniformis levansucrase producing levan with antitumor activity. International Journal of Biological Macromolecules, 51(3), 329-335. https://doi.org/10.1016/j.ijbiomac.2012.04.030

Debabov, V. G. (1982). The industrial use of Bacilli. In D.A. Dubnau (Ed.), The molecular biology of the Bacilli (Vol. 1, pp. 331-370). New York: Academic Press Inc.

Devi, P. U. (1989). Basics of Carcinogenesis. Health Administrator, 17(1), 16-24.

Donio, M. B. S., Ronica, S. F. A., Viji, V. T., Velmurugan, S., Jenifer, J. A., \& Michaelbabu, M. (2013). Isolation and characterization of halophilic Bacillus sp. BS3 able to produce pharmacologically important biosurfactants. Asian Pacific Journal of Tropical Medicine, 6(11), 876-883. https://doi.org/10.1016/S1995-7645(13)60156-X

Ekino, K., Okumura, S., Ishikawa, T., Kitada, S., Saitoh, H., Akao, T., ... Mizuki, E. (2014). Cloning and characterization of a unique cytotoxic protein parasporin-5 produced by Bacillus thuringiensis a1100 strain. Toxins, 6(6). https://doi.org/10.3390/toxins6061882 El-sersy, N. A., Abdelwahab, A. E., \& Abouelkhiir, S. S. (2012). Antibacterial and Anticancer activity of $\varepsilon$-poly-L-lysine ( $\varepsilon$-PL ) produced by a marine Bacillus subtilis sp . Journal of Basic Microbiology, 52, 1-10. https://doi.org/10.1002/jobm.201100290 
Eppinger, M., Bunk, B., Johns, M. A., Edirisinghe, J. N., Kutumbaka, K. K., Koenig, S. S K., ... Vary, P. S. (2011). Genome sequences of the biotechnologically important Bacillus megaterium Strains QM B1551 and DSM319. Journal of Bacteriology, 193(16), 4199-4213. https://doi.org/10.1128/JB.00449-11

Franken, J., Brandt, B. A., Tai, S. L., \& Bauer, F. F. (2013). Biosynthesis of levan, a bacterial extracellular polysaccharide, in the yeast Saccharomyces cerevisiae. PloS One, 8(10), e77499. https://doi.org/10.1371/journal.pone.0077499

Gallagher, M. P., Marshall, R. D., \& Wilson, R. (1989). Asparaginase as a drug for treatment of acute lymphoblastic leukaemia. Essays in Biochemistry, 24, 1-40.

GMT, C., Lima, R. C., de Franca, F. P., \& Lopes, C. E. (2000). Molecular weight and antitumour activity of Zymomonas mobilis levans. International Journal of Biological Macromolecules, 27(4), 245-247.

Gonzalez, E., Granados, J. C., Short, J. D., Ammons, D. R., \& Rampersad, J. (2011). Parasporins from a Caribbean Island: Evidence for a Globally Dispersed Bacillus thuringiensis Strain. Current Microbiology, 62(5), 1643-1648. https://doi.org/10.1007/s00284-011-9905-5

Goutam Dey, Rashmi Bharti, Indranil Banerjee, Anjan Kumar Das, Chandan Kanta Das, Subhayan Das, Bikash Chandra Jena, Mridula Misra, R. S. and M. M. (2016). Pre-clinica Risk Assessment and therapeutic potential of Antitumor Lipopeptide 'Iturin A' in in vivo and in vitro Model. RSC Advances. https://doi.org/10.1039/C6RA13476A

Gudina, E. J., Rangarajan, V., \& Sen, R. (2013). Potential therapeutic applications of biosurfactants. Trends in Pharmacological Sciences, 34(12), 667-675. https://doi.org/10.1016/j.tips.2013.10.002

Haavik, H. I. (1979). Bacitracin Production by The Neotype Bacillus licheniformis ATCC 14580. Acta Path. Microbiol. Scand. Sect. B, 15(1), 126-130.

Häcker, G. (2000). The morphology of apoptosis. Cell Tissue Res, 301, 5-17.

Halliwell, B., Gutteridge, J. M., \& Cross, C. E. (1992). Free radicals, antioxidants, and human disease: where are we now? The Journal of Laboratory and Clinical Medicine, 119(6), 598-620. https://doi.org/0022-2143(92)90284-R [pii]

Hamdache, A., Lamarti, A., \& Collado, I. G. (2011). Non-peptide Metabolites from the Genus Bacillus. Journal of Natural Products, 74, 893-899.

Harris, F., \& Pierpoint, L. (2012). Photodynamic therapy based on 5-aminolevulinic acid and its use as an antimicrobial Agent. Medicinal Research Reviews, 32(6), 1292-1327. https://doi.org/10.1002/med.20251

Henderson, B. E., Ross, R., \& Bernstein, L. (1988). Estrogens as a Cause of Human Cancer. Cancer Research, 48, 246-253.

Hoption Cann, S. A., van Netten, J. P., \& van Netten, C. (2003). Dr William Coley and tumour regression: a place in history or in the future. Postgraduate Medical Journal, 79(938), 672-80. Retrieved from http://www.ncbi.nlm.nih.gov/pubmed/14707241

Hoq, Md. Mozammel, Siddiquee, khandaker al Zaid, Kawasaki, Hiroko, seki, T. (2005). Keratinolytic Activity of Some Newly Isolated Bacillus Speices. Journal of Biological Sciences, 5(2), 193-200.

Isoldi, M. C., Visconti, M. A., Maria, A., \& Castrucci, D. L. (2005). Anti-Cancer Drugs $\rrbracket:$ Molecular Mechanisms of Action. Mini-Reviews in Medicinal Chemistry, 5(7), 685-695. Ito, A., Sasaguri, Y., Kitada, S., Kusaka, Y., Kuwano, K., Masutomi, K., ... Ohba, M. (2004). A Bacillus thuringiensis crystal protein with selective cytocidal action to human cells. Journal of Biological Chemistry, 279(20), 21282-21286. https://doi.org/10.1074/jbc.M401881200

Jacobs, M., Eliasson, M., Uhlén, M., \& Flock, J. I. (1985). Cloning, sequencing and expression of subtilisin Carlsberg from Bacillus licheniformis. Nucleic Acids Research,
13(24), 8913-26. https://doi.org/10.1093/nar/13.24.8913

Jeong, S., Park, S., Kim, Y., Kim, M., \& Lee, S. (2008). Cytotoxicity and apoptosis induction of Bacillus vallismortis BIT-33 metabolites on colon cancer carcinoma cells. $\begin{array}{llll}\text { Journal of } \quad \text { Applied } & \text { Microbiology, } & \text { 104, }\end{array}$ https://doi.org/10.1111/j.1365-2672.2007.03615.x

Kameda, Y., Matsui, K., Kato, H., Yamada, T., \& Sagai, H. (1972). Antitumor Activity of Bacillus natto. III. Isolation and Characterization of a Cytolytic Substance on Ehrlich Ascites Carcinoma Cells in the Culture Medium of Bacillus natto KMD 1126. Chemical \& Pharmaceutical Bulletin, 20(7), 1551-1557. https://doi.org/10.1248/cpb.20.1551

Kameda, Y., Oira, S., Matsui, K., Kanatomo, S., \& Hase, T. (1974). Antitumor activity of bacillus natto. $V$. Isolation and characterization of surfactin in the culture medium of Bacillus natto KMD 2311. Chemical \& Pharmaceutical Bulletin, 22(4), 938-44. Retrieved from http://www.ncbi.nlm.nih.gov/pubmed/4473150

Katayama, H., Kusaka, Y., Yokota, H., Akao, T., Kojima, M., Nakamura, O., ... Mizuki, E. (2007). Parasporin-1, a novel cytotoxic protein from Bacillus thuringiensis, induces $\mathrm{Ca} 2+$ influx and a sustained elevation of the cytoplasmic $\mathrm{Ca} 2+$ concentration in toxin-sensitive cells. Journal of Biological Chemistry, 282(10), 7742-7752. https://doi.org/10.1074/jbc.M611382200

Katayama, H., Yokota, H., Akao, T., Nakamura, O., Ohba, M., Mekada, E., \& Mizuki, E. (2005). Parasporin-1, a novel cytotoxic protein to human cells from non-insecticidal parasporal inclusions of Bacillus thuringiensis. Journal of Biochemistry, 137(1), 17-25. https://doi.org/10.1093/jb/mvi003

Kim, K. H., Chung, C. B., Kim, Y. H., Kim, K. S., Han, C. S., \& Kim, C. H. (2005). Cosmeceutical properties of levan produced by Zymomonas mobilis. Journal of Cosmetic Science, 56(6), 395-406.

Kumar, D., Savitri, Thakur, N., Verma, R., \& Bhalla, T. (2008). Microbial Proteases and Application as Laundry Detergent Additives. Research Journal of Microbiology, 3(12), $661-672$.

Kumar, M. L. V., Thippeswamy, B., \& Raj, P. V. (2014). Cytotoxicity and Anticancer Studies of Bacillus cereus and Bacillus pumilus Metabolites Targeting Human Cancer Cells 1. Applied Biochemistry and Microbiology, 50(6), 619-623. https://doi.org/10.1134/S0003683814060088

Kumar, S. N., Nambisan, B., Kumar, B. S. D., Vasudevan, N. G., Mohandas, C., Cheriyan, V. T., \& Anto, R. J. (2013). Antioxidant and anticancer activity of 3,5-dihydroxy-4-isopropylstilbene produced by Bacillus sp. $\mathrm{N}$ strain isolated from entomopathogenic nematode. Archives of Pharmacal Research, (3), 1-11. https://doi.org/10.1007/s12272-013-0207-2

Lee, N. K., Park, J. S., Park, E., \& Paik, H. D. (2007). Adherence and anticarcinogenic effects of Bacillus polyfermenticus SCD in the large intestine. Letters in Applied Microbiology, 44(3), 274-278. https://doi.org/10.1111/j.1472-765X.2006.02078.x

Li, C. (2013). Antitumor activity of bacterial exopolysaccharides from the endophyte Bacillus amyloliquefaciens sp. isolated from Ophiopogon japonicus. Oncology Letters, 5(548), 1787-1792. https://doi.org/10.3892/ol.2013.1284

Li, Y., Xu, Y., Liu, L., Han, Z., Lai, P. Y., Guo, X., ... Qian, P. (2012). Five New Amicoumacins Isolated from a Marine-Derived Bacterium Bacillus subtilis. Marine Drugs, 10, 319-328. https://doi.org/10.3390/md10020319

Lin X, Lee CG, Casale ES, S. J. (1992). Purification and characterization of a keratinase from a degrading Bacillus licheniformis strain. Appl Environ Microbiol, 58:(10), $3271-3275$.

Liu, L., Liu, Y., Shin, H., Chen, R. R., Wang, N. S., Li, J., ... Chen, J. (2013). Developing 
Bacillus spp. as a cell factory for production of microbial enzymes and industrially important biochemicals in the context of systems and synthetic biology. Applied Microbiology and Biotechnology, 97(14), 6113-6127. https://doi.org/10.1007/s00253-013-4960-4

Ma, Elise L., Choi, Y. J., Choi, J., Pothoulakis, C., Rhee, S. H., Im, E., Bowel, I., \& Angeles, L. (2015). The anti-cancer effect of probiotic Bacillus polyfermenticus on human colon cancer cells is mediated through ErbB2 and ErbB3 inhibition. Int $J$ Cancer., 127(4), 780-790. https://doi.org/10.1002/ijc.25011.The

Ma, E. L., Choi, Y. J., Choi, J., Pothoulakis, C., Rhee, S. H., \& Im, E. (2010). The anticancer effect of probiotic Bacillus polyfermenticus on human colon cancer cells is mediated through ErbB2 and ErbB3 inhibition. International Journal of Cancer, 127(4), 780-90. https://doi.org/10.1002/ijc.25011

Ma, Z., Wang, N., Hu, J., \& Wang, S. (2012). Isolation and characterization of a new iturinic lipopeptide, mojavensin A produced by a marine-derived bacterium Bacillus mojavensis. The Journal of Antibiotics, 65(6), 317-322. https://doi.org/10.1038/ja.2012.19

Mahajan, R. V, Kumar, V., Rajendran, V., Saran, S., Ghosh, P. C., \& Saxena, R. K. (2014) Purification and Characterization of a Novel and Robust L-Asparaginase Having Low-Glutaminase Activity from Bacillus licheniformis: In Vitro Evaluation of Anti-Cancerous Properties. PLoS One, 9(6), e99037. https://doi.org/10.1371/journal.pone.0099037

Makkar, R. S., Cameotra, S. S., \& Banat, I. M. (2011). Advances in utilization of renewable substrates for biosurfactant production. AMB Express, 1(1), 5 . https://doi.org/10.1186/2191-0855-1-5

Malkov, S. V, Markelov, V. V, Polozov, G. Y., \& Sobchuk, L. I. (2005). Antitumor features of Bacillus oligonitrophilus KU-1 strain. J Microbiol Immunol Infect, 38, 96-104.

Mashburn, L. T., \& Wriston, J. C. (1963). Tumor inhibitory effect of L-asparaginase. Biochemical and Biophysical Research Communications, 12(1), 50-55 https://doi.org/10.1016/0006-291X(63)90412-1

Mccredie, K. B., Ho, D. H. W., \& EmilJ. Freireich. (1953). L-Asparaginase forthe Treatmentof Cancer. CA: A Cancer Journal for Clinitians, 23(4), 220-228.

Meena, K. R., Sharma, A., \& Kanwar, S. S. (2017). Microbial Lipopeptides and their Medical Applications. Annals of Pharmacology and Pharmaceutics, 2(21), 1-5.

Mizuki, E., Ohba, M., Akao, T., Yamashita, S., Saitoh, H., \& Park, Y. S. (1999). Unique activity associated with non-insecticidal Bacillus thuringiensis parasporal inclusions: in vitro cell-killing action on human cancer cells. Journal of Applied Microbiology, 86(3) 477-486. https://doi.org/10.1046/j.1365-2672.1999.00692.x

Nagamatsu, Y., Okamura, S., Saitou, H., Akao, T., \& Mizuki, E. (2010). Three Cry toxins in two types from Bacillus thuringiensis strain M019 preferentially kill human hepatocyte cancer and uterus cervix cancer cells. Bioscience, Biotechnology, and Biochemistry, 74(3), 494-8. https://doi.org/10.1271/bbb.90615

Nahar, M., Shishir, M. A., Waliullah, S., Haque, M. S., Ilias, M., Karim, M. M., ... Hoq, M. M. (2016). Cloning, expression and structure simulation of keratinase from Bacillus licheniformis strain MZK05. Malaysian Journal of Microbiology, 12(2), 182-190. https://doi.org/10.21161/mjm.78515

Nandakumar, N., Jayaprakash, R., Rengarajan, T., Ramesh, V., \& Balasubramanian, M. P. (2011). Hesperidin, a natural citrus flavonoglycoside, normalizes lipid peroxidation and membrane bound marker enzymes in 7, 12-Dimethylbenz ( a ) anthracene induced experimental breast cancer rats. Biomedicine \& Preventive Nutrition, 1(4), 255-262. https://doi.org/10.1016/j.bionut.2011.06.004

Okumura, S., Koga, H., Inouye, K., \& Mizuki, E. (2014). Toxicity of Parasporin-4 and Health Effects of Pro-parasporin-4 Diet in Mice. Toxins, 6, 2115-2126. https://doi.org/10.3390/toxins6072115

Okumura, S., Ohba, M., Mizuki, E., Crickmore, N., Côté, J.-C., Nagamatsu, Y., ... Shin, T. (2010). Parasporin nomenclature. Retrieved December 10, 2017, from http://parasporin.fitc. pref.fukuoka.jp/

Okumura, S., Saitoh, H., Ishikawa, T., Inouye, K., \& Mizuki, E. (2011). Mode of action of parasporin-4, a cytocidal protein from Bacillus thuringiensis. Biochimica et Biophysica Acta, 1808(6), 1476-1482. https://doi.org/10.1016/j.bbamem.2010.11.003

Papagianni, M. (2012). Recent advances in engineering the central carbon metabolism of industrially important bacteria. Microbial Cell Factories. https://doi.org/10.1186/1475-2859-11-50

Park, G. H., Song, H. M., Kim, Y. S., Jeon, Y., Koo, J. S., Jeong, H. J., \& Jeong, J. B. (2017). Anti-cancer activity of Bacillus amyloliquefaciens AK-0 through cyclin D1 proteasomal degradation via GSK3 $\beta$-dependent phosphorylation of threonine-286. Die Pharmazie, 72(6), 348-354. https://doi.org/10.1691/ph.2017.6199

Parsonnet, J. (1995). Bacterial Infection as a Cause of Cancer. Environmental Health Perspectives, (7), 263-268.

Parthiban, K., Vignesh, V., \& Thirumurugan, R. (2014). Characterization and in vitro studies on anticancer activity of exopolymer of Bacillus thuringiensis S13. African Journal of Biotechnology, 13(21), 2137-2144. https://doi.org/10.5897/AJB2014.13741

Patyar, S., Joshi, R., Byrav, D. S. P., Prakash, A., Medhi, B., \& Das, B. K. (2010). Bacteria in cancer therapy: a novel experimental strategy. Journal of Biomedical Science, 17(1), 21. https://doi.org/10.1186/1423-0127-17-21

Payne, S., \& Miles, D. (2008). Mechanisms of anticancer drugs. In Scott-Brown's Otorhinolaryngology: Head and Neck Surgery (7th ed., pp. 34-46).

Pettit, G. R., Arce, P. M., Chapuis, J. C., \& Macdonald, C. B. (2015). Antineoplastic agents. 600. from the south pacific ocean to the silstatins. Journal of Natural Products, 78(3), 510-523. https://doi.org/10.1021/np501004h

Pettit, G. R., Knight, J. C., Herald, D. L., Pettit, R. K., Hogan, F., Mukku, J. R. V, ... Chapuis, J. (2010). Antineoplastic Agents. 570. Isolation and Structure Elucidation of Bacillistatins 1 and 2 from a Marine Bacillus silvestris. J Nat Prod., 72(3), 366-371. https://doi.org/10.1021/np800603u.Antineoplastic

Piggot, P. J. (2009). Bacillus Subtilis A2 - Schaechter, Moselio BT - Encyclopedia of Microbiology (Third Edition) (pp. 45-56). Oxford: Academic Press. https://doi.org/https://doi.org/10.1016/B978-012373944-5.00036-5

Pisha Emily, Chai Heebyung, Lee Ik-Soo, Chagwedera Tangai E, F. N. R. et al. (1995). Discovery of betulinic acid as a selective inhibitor of human melanoma that functions by induction of apoptosis. Nature Medicine, 1, 1046-1051.

Poornima, K., Selvanayagam, P., \& Shenbagarathai, R. (2010). Identification of native Bacillus thuringiensis strain from South India having specific cytocidal activity against cancer cells. Journal of Applied Microbiology, 4, 348-354. https://doi.org/10.1111/j.1365-2672.2010.04697.x

Porwal, S., Lal, S., Cheema, S., \& Kalia, V. C. (2009). Phylogeny in aid of the present and novel microbial lineages: diversity in Bacillus. PloS One, 4(2), e4438. https://doi.org/10.1371/journal.pone.0004438

Prasad, S. S., \& Shethna, Y. I. (1974). Purification, crystallization and partial characteri- 


\section{REVIEWS}

zation of the antitumour and insecticidal protein subunit from the delta-endotoxin of Bacillus thuringiensis var. thuringiensis. Biochimica et Biophysica Acta, 362(3), $558-566$.

Prokhorova, I. V., Akulich, K. A., Makeeva, D. S., Osterman, I. A., Skvortsov, D. A., Sergiev, P. V., ... Dmitriev, S. E. (2016). Amicoumacin A induces cancer cell death by targeting the eukaryotic ribosome. Scientific Reports, 6(1), 27720 https://doi.org/10.1038/srep27720

Queiroz, E. A. I. F., Fortes, Z. B., da Cunha, M. A. A., Sarilmiser, H. K., Barbosa Dekker, A. M., Öner, E. T., ... Khaper, N. (2017). Levan promotes antiproliferative and pro-apoptotic effects in MCF-7 breast cancer cells mediated by oxidative stress. International Journal of Biological Macromolecules, 102, 565-570. https://doi.org/10.1016/j.ijbiomac.2017.04.035

Radha, S., \& Gunasekaran, P. (2007). Cloning and expression of keratinase gene in Bacillus megaterium and optimization of fermentation conditions for the production of keratinase by recombinant strain. Journal of Applied Microbiology, 103(4), 1301-10. https://doi.org/10.1111/j.1365-2672.2007.03372.x

Ramasubburayan, R., Sumathi, S., Bercy, D. M., Immanuel, G., \& Palavesam, A. (2015) Antimicrobial, antioxidant and anticancer activities of mangrove associated bacterium Bacillus subtilis subsp. subtilis RG. Biocatalysis and Agricultural Biotechnology, 4(2), 158-165. https://doi.org/10.1016/j.bcab.2015.01.004

Reddy, L., Odhav, B., \& Bhoola, K. D. (2003). Natural products for cancer prevention: A global perspective. Pharmacology and Therapeutics, 99(1), 1-13. https://doi.org/10.1016/S0163-7258(03)00042-1

Reid, G., Jass, J., Sebulsky, M. T., \& McCormick, J. K. (2003). Potential uses of probiotics in clinical practice. Clinical Microbiology Reviews, 16(4), 658-72. https://doi.org/10.1128/CMR.16.4.658

Rey, M. W., Ramaiya, P., Nelson, B. A., Brody-Karpin, S. D., Zaretsky, E. J., Tang, M., ... Berka, R. M. (2004). Complete genome sequence of the industrial bacterium Bacillus licheniformis and comparisons with closely related Bacillus species. Genome Biol., 5(1465-6914 (Electronic)), R77. https://doi.org/10.1186/gb-2004-5-10-r77

Roberts, E. R., \& Jean, K. (2013). The role of mitochondria in the development and progression of lung cancer Abstract冈: The influence of mitochondria in human health and disease is a rapidly expanding topic in the scientific literature due to their integra roles in cellular death and sur. Computational and Structural Biotechnology, 6(7), 1-11. https://doi.org/10.5936/csbj.201303019

Sahai, E. (2007). Illuminating the metastatic process. Nature Reviews Cancer, 7(10), 737-749. https://doi.org/10.1038/nrc2229

Sareen, R., Bornscheuer, U. T., \& Mishra, P. (2005). Cloning, functional expression and characterization of an alkaline protease from Bacillus licheniformis. Biotechnology Letters, 27(23-24), 1901-7. https://doi.org/10.1007/s10529-005-3901-4

Seerangaraj, V., KannanSuruli, Vijayakumar, U., Meganathan, B., Seerangaraj, V., Selvam, S., ... Selvaraj, J. (2017). Isolation and Characterization of Bioactive Compounds from Bacillus cereus and Bacillus subtilis from Oreochromis mossambicus and Labeo rohita. International Journal of Pharmaceutical Sciences Review and Research, 43(2), 71-77.

Shrivastava, A., Khan, A. A., Khurshid, M., Kalam, M. A., Jain, S. K., \& Singhal, P. K. (2016). Recent developments in I-asparaginase discovery and its potential as anticancer agent. Critical Reviews in Oncology/Hematology, 100, 1-10. https://doi.org/10.1016/j.critrevonc.2015.01.002

Slepecky, R. A., \& Hemphill, H. E. (2006). The Genus Bacillus-Nonmedical. The
Prokaryotes. https://doi.org/10.1007/0-387-30744-3_16

Steller, H. (1995). Mechanisms and genes of cellular suicide. Science, 267(5203), 1445-1449. https://doi.org/10.1126/science.7878463

Strobel, G., Daisy, B., Castillo, U., \& Harper, J. (2004). Natural Products from Endophytic Microorganisms. J. Nat. Prod., 67, 257-268.

Szende, B., Szökán, G., Tyihá, E., Pál, K., Gáborjányi, R., Almás, M., \& Khlafulla, A. R. (2002). Antitumor effect of lysine-isopeptides. Cancer Cell International, 7, 1-7.

Tang, X.-M., Shen, W., Lakay, F. M., Shao, W.-L., Wang, Z.-X., Prior, B. A., \& Zhuge, J. (2004). Cloning and over-expression of an alkaline protease from Bacillus licheniformis. Biotechnology Letters, 26(12), 975-9. https://doi.org/10.1023/B

Tareq, F. S., Kim, J. H., Lee, M. A., Lee, H.-S., Lee, Y.-J., Lee, J. S., \& Shin, H. J. (2013). leodoglucomides A and B from a Marine-Derived Bacterium Bacillus licheniformis. Organic Letters, 15(8), 2071-2071. https://doi.org/10.1021/ol4008603

Tiwary, E., \& Gupta, R. (2010). Medium optimization for a novel 58 kDa dimeric keratinase from Bacillus licheniformis ER-15: Biochemical characterization and application in feather degradation and dehairing of hides. Bioresource Technology, 101(15), 6103-6110. https://doi.org/10.1016/j.biortech.2010.02.090

Trischman, J. A., Jensen, P. R., \& Fenical, W. (1994). Halobacillin: A cytotoxic cyclic acylpeptide of the iturin class produced by a marine Bacillus. Tetrahedron Letters, 35(31), 5571-5574. https://doi.org/10.1016/S0040-4039(00)77249-2

van Dijl, J. M., \& Hecker, M. (2013). Bacillus subtilis囚: From soil bacterium to supersecreting cell factory. Microbial Cell Factories, 12, 3. https://doi.org/10.1186/1475-2859-12-3

Veith, B., Herzberg, C., Steckel, S., Feesche, J., Maurer, K. H., Ehrenreich, P., ... Gottschalk, G. (2004). The complete genome sequence of Bacillus licheniformis DSM13, an organism with great industrial potential. Journal of Molecular Microbiology and Biotechnology, 7(4), 204-211. https://doi.org/10.1159/000079829

Vijayaram Seerangaraja*, KannanSurulia, Usharani Vijayakumarb, Boominathan Meganathanc, V. S., \& Sathiyavimal Selvame, Vijayakumar Rajendran f, J. S. (2017). "Isolation and Characterization of Bioactive Compounds from Bacillus cereus and Bacillus subtilis from Oreochromi.... Int. J. Pharm. Sci. Rev. Res., 43(2), 71-77.

Weston, A., \& Harris, C. C. (2003). Multistage Carcinogenesis. In D. W. Kufe, W. Hait, J. F. Holland, E. Frei, \& R. E. Pollock (Eds.), Holland-Frei Cancer Medicine (6th ed.). Hamilton (ON): BC Decker; 2003. Retrieved from https://www.ncbi.nlm.nih.gov/books/NBK13982/

WHO media center. (2017). Cancer fact sheet. Retrieved from http://www.who.int/mediacentre/factsheets/fs297/en/

Wu, Y. S., Ngai, S. C., Goh, B. H., Chan, K. G., Lee, L. H., \& Chuah, L. H. (2017). Anticancer activities of surfactin potential application of nanotechnology assisted surfactin delivery. Frontiers in Pharmacology, 8(OCT), 1-22. https://doi.org/10.3389/fphar.2017.00761

Wyllie, A. H. (1992). Apoptosis and the regulation of cell numbers in normal and neoplastic tissues $\bowtie$ : an overview. Cancer and Metastasis Reviews, 11, 95-103.

Xu, C., Wang, B.-C., \& Yu, Ziniu and Sun, M. (2014). Structural Insights into Bacillus thuringiensis Cry, Cyt and Parasporin Toxins. Toxins, 6, 2732-2770. https://doi.org/10.3390/toxins6092732

Yamashita, S., Katayama, H., Saitoh, H., Akao, T., Park, Y. S., Mizuki, E., ... Ito, A. (2005). Typical three-domain cry proteins of Bacillus thuringiensis strain A1462 exhibit cytocidal activity on limited human cancer cells. Journal of Biochemistry, 138(6), 663-672. https://doi.org/10.1093/jb/mvi177 
Yeo, C. D., Kang, N., Choi, S. Y., Kim, B. N., Park, C. K., Kim, J. W., ... Kim, S. J. (2017). The role of hypoxia on the acquisition of epithelial-mesenchymal transition and cancer stemness: A possible link to epigenetic regulation. Korean Journal of Internal Medicine, 32(4), 589-599. https://doi.org/10.3904/kjim.2016.302

Yokota, J. (2000). Tumor progression and metastasis . Carcinogenesis, 21(3), 497-503. Retrieved from http://dx.doi.org/10.1093/carcin/21.3.497

Yoo, S., Yoon, E. J., Cha, J., \& Lee, H. G. (2004). Antitumor activity of levan polysaccharides from selected microorganisms. International Journal of Biological Macromolecules, 34(1-2), 37-41. https://doi.org/10.1016/j.ijbiomac.2004.01.002 Yoshioka, K., Saito, M., Oh, K.-B., Nemoto, Y., Matsuoka, H., Natsume, M., \& Abe, H. (1996). Intracellular Fate of 2-NBDG, a Fluorescent Probe for Glucose Uptake Activity, in Escherichia coli Cells. Bioscience, Biotechnology, and Biochemistry, 60(11), 1899-1901. https://doi.org/10.1271/bbb.60.1899

Yu, A., \& Li, L. (2016). The Potential Role of Probiotics in Cancer Prevention and Treatment. Nutrition and 1-10. https://doi.org/10.1080/01635581.2016.1158300

Zacharski, L. R., \& Sukhatme, V. P. (2005). Coley's toxin revisited: immunotherapy or plasminogen activator therapy of cancer? Journal of Thrombosis and Haemostasis, 3(3), 424-7. https://doi.org/10.1111/j.1538-7836.2005.01110.x

ZHang, H. L., Hua, H. M., \& Pei, Y. H. (2004). Three New Cytotoxic Cyclic Acylpeptides from Marine Bacillus sp . Chem. Pharm. Bull., 52(8), 1029-1030 